guidance to several generations of African history students who now follow his approach in many of Africa's universities. Dr. Pereira's award is for his work in establishing one of the leading soil physics research departments in the tropics and in carrying out scientific work to the considerable benefit of African peoples. The 1966 Award for Ethiopian Studies has been made to Professor Rudolfo E. G. Pichi Sermolli, for botanical studies in Ethiopia and the Horn of Africa.

\title{
Field Research in Southern Somalia
}

Miss Virginia Luling, research assistant, Department of Anthropology, University College London, is currently carrying out field research on the social structure of southern Somali communities. The project, which began in July and is planned to run for two years, is financed by the British Social Science Research Council, with additional assistance from the Horniman Trust, and directed by Dr. I. M. Lewis. The aim of the study is to investigate the social structures of selected southern cultivating communities in the Somali Republic, with special reference to ecology, economics, and the ritualization of conflict. Comparable detailed material is already available for the kindred pastoral nomadic Somali of the north of the Republic who share the same general culture as the southern cultivators but differ considerably in social structure within what is virtually a common culture area. It will thus be possible to examine the contrasting effects upon social structure of the two variables: cultural and pastoral nomadism, and to relate these to different sociological conditions. A detailed study of the annual new-year fertility festival characteristic of the area should also throw new light on conflict rituals.

\section{'Sierra Leone Studies'}

Sierra Leone Studies is issued twice a year, in January and July, by the Institute of African Studies of Fourah Bay College, the University College of Sierra Leone, under the editorship of Mr. Michael Crowder, Director of the Institute. It is now the journal of the Sierra Leone Society and the editor is advised by a Committee of the Society.

\section{'African Scriptures'}

THE British and Foreign Bible Society is bringing out a revised version of Darlow and Moule's standard work, The Historical Catalogue of Printed Bibles, on a sectional basis. Miss Geraldine Coldham, Deputy Librarian of the B.F.B.S., has produced a complete revision in two volumes of the section dealing with African Scriptures, providing up-to-date details of all accessible Scriptures in over 400 African languages.

\section{The Congolese Academy}

THE Congolese Academy is a school and ' rural research centre' started by M. André Fukiau in the northern (Manianga) region of the Lower Congo. In addition to the teaching of French, history, mathematics, natural science, etc., M. Fukiau aims to instruct students in their own historic traditions and to encourage them and adults to write about these and traditional and contemporary social, political, and religious institutions. Some of these writings-the majority in Kikongo and other Congolese languages-and works by $M$. Fukiau himself have been mimeographed and are on sale. Further information may be obtained from: M. André Fukiau (please write in French), Académie Congolaise, B.P. I I, 
Mondouli, Republic of the Congo (Brazzaville), or Mr. John M. Jansen, c/o Department of Anthropology, University of Chicago, Chicago, Illinois, U.S.A.

(Abridged from a communication by Mr. John M. Janzen)

\section{First African Population Conference, Ibadan, Nigeria, January 1966}

THE conference was sponsored and made possible by the Population Council of New York and excellently organized by Dr. Okonjo of the Centre of Population Studies, University of Ibadan, and Dr. Caldwell of the Australian National University. It provided the opportunity for some one hundred persons concerned with African population studies-demographers, sociologists, medicals, geographers, and others-to meet for inter-disciplinary discussion in this broad field. Representatives from eleven English-speaking countries and from twelve universities in tropical Africa were present, together with a number of students of African population from overseas. Preparatory to the conference more than fifty papers were submitted and these were circulated to participants. At the conference itself it was thus possible to apportion the major amount of time to discussion. This was always lively and valuable, and covered a wide range of topics-problems of census and planning for the next round of censuses, the need for vital statistics, and accelerating rates of population change to receive greater attention in development plans, being among the more important. Several visits of demographic interest were arranged in and around Ibadan. A most useful opportunity was provided for the interchange of ideas and information and in conclusion the conference passed a number of resolutions. These concerned the importance of reprinting Kuczynski's classic Demographic Survey of the British Empire with comments on this work in the light of current information, making available data with a central library of deposit for these in each African country, forming an association of statisticians and publishing a journal, and the urgent need for improving conditions for demographers and statisticians in government service in Africa. Papers submitted for the conference, together with the discussions, are being edited for publication, it is hoped, in 1967 .

(Communicated by Dr. R. Mansell Prothero)

\section{'The Small Brave City-State'}

WE have received the following comments on the review by G. I. Jones of The Small Brave City-State: a History of Nembe-Brass in the Niger Delta, by Ebiegberi Joe Alagoa (Africa, xxxvi. 3, I966, pp. 339-40):

Dr. E. J. Alagoa (Institute of African Studies, University of Ibadan) writes:

'Allow me to make a few comments about Mr. G. I. Jones's review of my book, The Small Brave City-State: a History of Nembe-Brass in the Niger Delta.

'Mr. Jones strikes me as a man trying to stake out claims to territory, and therefore intolerant of trespassers. He has treated other contributors to Niger Delta history with similar intolerance. In a previous review of Dr. K. O. Dike's Trade and Politics in the Niger Delta (Africa, vol. xxvii, no. I, pp. 83-85), he had insisted that certain sections of the book needed to be "revised" and unless that was done, the book would be unfair to the Bonny people! In the final paragraph of his present review, he goes beyond attack of my alleged unfairness to the Nembe state to impugn the scholarly integrity of all who had dared to encourage my first efforts.

'Mr. Jones's claims to be an authority on Niger Delta history are based on a number of years in the Nigerian administration (none of which seem to have been spent in the delta), 